\title{
DAMPAK IMPLEMENTASI MANDAT KONSUMSI BAHAN BAKAR NABATI TERHADAP PEREKONOMIAN INDONESIA ${ }^{1}$
}

\author{
Sugiyono $^{1}$, Rina Oktaviani ${ }^{2}$, Dedi Budiman Hakim $^{2}$, Bustanul Arifin ${ }^{3}$ \\ ${ }^{1}$ Mahasiswa Pascasarjana, IPB \\ ${ }^{2}$ Departemen Ilmu Ekonomi, Fakultas Ekonomi dan Manajemen \\ Institut Pertanian Bogor \\ ${ }^{3}$ Universitas Negeri Lampung \\ Artikel diterima Mei 2012 \\ Artikel disetujui untuk dipublikasikan Juli 2012
}

\begin{abstract}
Before 2006, biofuel mandate consumption was expected to contribute to increase economic growth and job creation, decrease poverty, mitigate climate change, and improve energy security. The objective of the study is an analysis of implementation of biofuel mandate in Indonesian economy. This research applied the long run of Recursive Dynamic General Equilibrium (RDGE) model by Indonesian Forecasting. Three simulations are used to increase of biofuel demand, seconds to increase of biofuel agriculture land expansion, deforestation, and rise fixed capital, and to last change agricultural and biofuel productivity. The policy of biofuel mandate implementation is effectively to increase economic growth, rise household income, and improve carbon emission, but less effective to built food security and feed, decline employment by industri for non biofuel agriculture, and descend forest and other forest outputs in Indonesia. The policy implication is to increase output for non biofuel agriculture by rising productivity and policy of import and inflation targetting to take sides for welfare farmer's and food employee's.
\end{abstract}

Keywords: Biofuel, RDGE, food security, carbon emission

\begin{abstract}
ABSTRAK
Sebelum tahun 2006, mandat penggunaan biofuel diperkirakan akan memberikan kontribusi terhadap peningkatan pertumbuhan ekonomi dan penciptaan lapangan kerja, pengurangan kemiskinan, pengendalian perubahan iklim, dan peningkatan ketahanan energi. Tujuan dari penelitian ini adalah menganalisis pelaksanaan mandat biofuel dalam perekonomian Indonesia. Penelitian ini menggunakan jangka panjang model Recursive Dynamic General Equilibrium $(R D G E)$ dengan Indonesian Forecasting. Tiga simulasi digunakan untuk meningkatkan permintaan biofuel, meningkatkan ekspansi lahan pertanian biofuel, mengurangi penggundulan hutan, dan meningkatkan modal tetap, serta mengubah produktivitas pertanian dan biofuel. Kebijakan pelaksanaan mandat biofuel secara efektif adalah untuk meningkatkan pertumbuhan ekonomi, pendapatan rumah tangga, dan mengurangi emisi karbon, tetapi kurang efektif untuk membangun ketahanan pangan dan pakan, menurunkan tenaga kerja oleh industri pertanian non biofuel, dan menurunkan output hutan dan lainnya di Indonesia. Implikasi kebijakan tersebut adalah meningkatkan output untuk pertanian non biofuel dengan meningkatkan produktivitas dan kebijakan impor dan inflasi dengan target yang berpihak pada kesejahteraan petani dan makanan karyawan.
\end{abstract}

Kata kunci : Biofuel, RDGE, ketahanan pangan, emisi karbon 


\section{I.PENDAHULUAN}

\subsection{Latar Belakang}

Inpres nomor 1 tahun 2006 tentang penyediaan dan pemanfaatan Bahan Bakar Nabati (BBN) sebagai bahan bakar lain ditetapkan oleh pemerintah untuk mengantisipasi kelangkaan Bahan Bakar Minyak (Setkab, 2006). Pemerintah juga menetapkan Perpres nomor 5 tahun 2006 tentang Kebijakan Energi Nasional, yang mencantumkan sasaran (mandat) konsumsi BBN lebih besar dari 5 persen pada tahun 2025 (Setkab, 2006a). Roadmap Kementerian ESDM merencanakan konsumsi biosolar sebesar 15 persen dan bioetanol sebesar 10 persen pada tahun 2011-2015. BBN dikembangkan oleh pemerintah untuk memenuhi konsep Triple Track Strategy, yaitu: pro-growth, pro-jobs, dan propoor (Departemen ESDM, 2008). Projobs dimaksudkan untuk membuka lapangan pekerjaan melalui pengembangan $\mathrm{BBN}$, pro-poor dengan cara mensubtitusi minyak tanah dengan BBN, dan dengan konsep progrowth dimaksudkan sebagai kegiatan ekonomi untuk meningkatkan pertumbuhan ekonomi (Departemen ESDM, 2008).

Sampai tahun 1996, BBN semula dipandang oleh banyak kalangan di dunia berpotensi melonggarkan perubahan iklim global, berperan terhadap keamanan energi dan membantu produsen pertanian di dunia (FAO, 2008). Ziegler (2008) mengatakan bahwa produksi besarbesaran BBN berdampak negatif terhadap persediaan makanan global. BBN juga diduga mencemari udara, air, dan memproduksi limbah. Beeman (2007) dan Dillon et al (2008) mengatakan bahwa produksi etanol dan biosolar tahun 2001-2007 di Amerika
Serikat terkena ketentuan UndangUndang (UU) Perlindungan Kesehatan dan UU Lingkungan. Koh dan Wilcove (2007) dalam Dillon et al (2008) menemukan bahwa luas hutan Indonesia tahun 1990-2005 menurun sebesar 28 juta hektar, sekitar 1.7 juta hektar lahan dikonversi menjadi tanaman kelapa sawit (6 persen dari deforestasi).

\subsection{Tujuan dan Manfaat Penelitian}

Tujuan umum penelitian ini adalah untuk menganalisis dampak implementasi mandat konsumsi BBN terhadap perekonomian Indonesia. Tujuan khusus penelitian ini adalah untuk menganalisis dampak peningkatan konsumsi $\mathrm{BBN}$, perubahan luas lahan dan peningkatan modal tetap, serta perubahan produktivitas terhadap keragaan ekonomi makro, pangan, pakan, dan emisi karbon. Penelitian ini diharapkan bermanfaat untuk pemerintah sebagai pengambilan keputusan dalam mengembangkan BBN, serta sebagai informasi untuk penelitian lain, sektor swasta, dan lembaga swadaya masyarakat (LSM) lingkungan hidup.

\section{METODOLOGI PENELITIAN}

\subsection{Kerangka Pemikiran}

Kerangka pemikiran penelitian ini disajikan pada Gambar 1. Inpres Nomor1 tahun 2006, Perpres Nomor 5 tahun 2006, dan Roadmap pemanfaatan BBN menjadi rujukan kebijakan mandat konsumsi BBN. Mandat tersebut didekati menggunakan peningkatan konsumsi BBN, perubahan luas lahan dan peningkatan modal tetap, serta perubahan produktivitas. Analisis dampak difokuskan kepada ketahanan pangan, pro-growth, pro-jobs, pro-poor, dan pro-environment. 


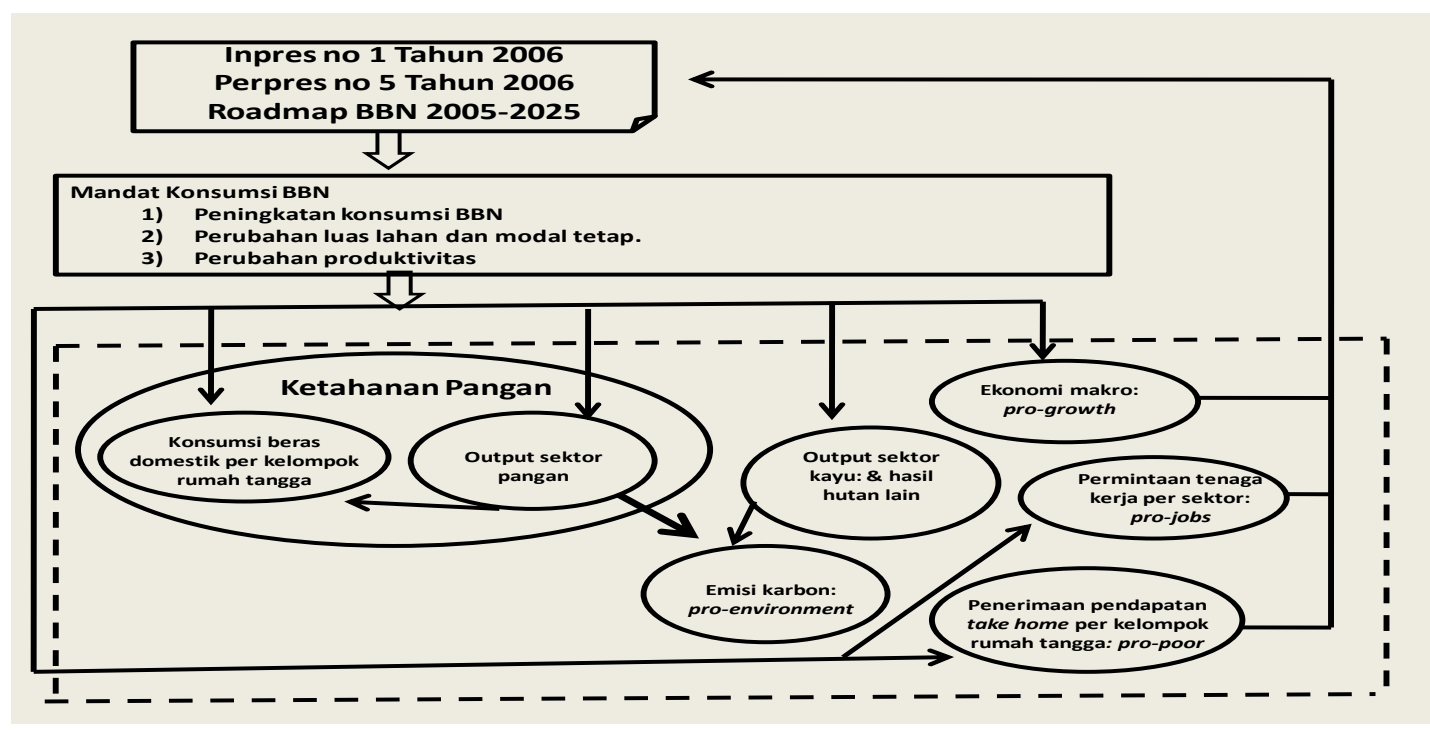

Gambar 1. Kerangka Pemikiran Penelitian

\subsection{Jenis dan Sumber Data}

Jenis data yang digunakan adalah data sekunder. Data dan sumber data untuk membangun konstruksi data dasar adalah Tabel Input Output (I-O) 66 sektor tahun 2008 (BPS, 2009), Tabel Sistem Neraca Sosial Ekonomi (SNSE) tahun 2005 (BPS, 2008), dan journal emisi karbon (Rodriguez, 2009).

\subsection{Metoda Pengolahan Data}

Pengolahan data menggunakan software GEMPACK release 10.0 dan Excel. Produktivitas per sektor dihitung menggunakan data Total Faktor
Produksi dari Jungsoo Park Tahun 2000-2007 (Park, 2010) dan data pertumbuhan PDB sektoral tahun 20002007 (www.bi.go.id) dikalikan faktor konversi sebesar 11.2 (Lampiran 1). Closure merupakan "penutup" model yang terdiri dari peubah eksogen dan endogen (Gambar 2). Model menggunakan asumsi terdapat mobilitas modal, tenaga kerja, dan lahan. Baseline merupakan estimasi kondisi ekonomi dalam keadaan normal tahun 2010. Hasil estimasi simulasi (updating) merupakan kondisi baseline + shock pada tahun 2015.

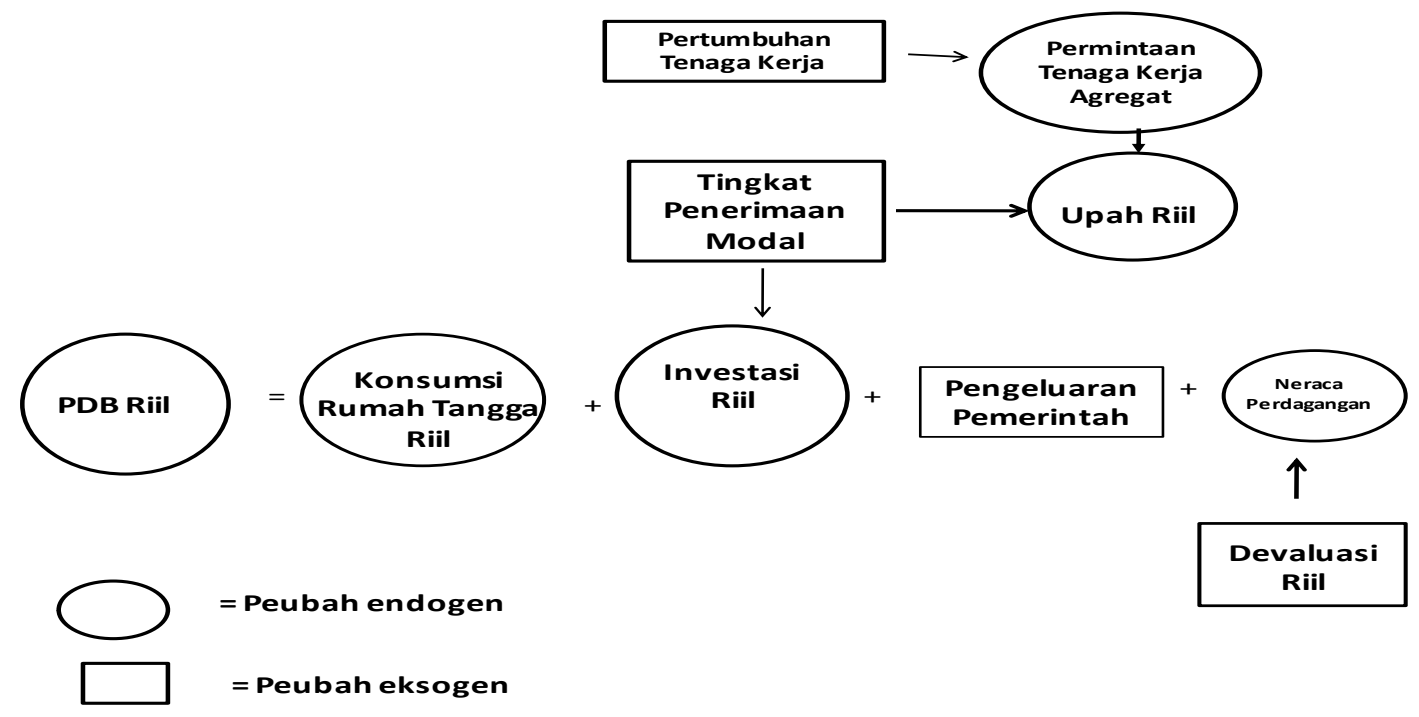

Gambar 2. Closure Makroekonomi yang Digunakan pada Penelitian 


\subsection{Struktur Model}

Model yang digunakan adalah model INDOF (Indonesian Forcasting Model) yang dibangun oleh Oktaviani (2008). Model tersebut dikembangkan dari model ORANI-F oleh Horridge et al (1993) dan Oktaviani (2000 dan 2008).

\subsection{Sistem Persamaan}

Sistem persamaan yang digunakan sebanyak 17 blok menggunakan keseimbangan umum recursive dynamic jangka panjang (Oktaviani, 2008). Sistem persamaan tersebut terdiri dari: (1) Permintaan untuk tenaga kerja, (2) Permintaan untuk input primer, (3) Permintaan untuk input antara, (4) Permintaan gabungan input primer dan input antara, (5) Gabungan komoditi dari output industri, (6) Permintaan untuk barang-barang investasi, (7) Permintaan rumah tangga, (8) Ekspor dan permintaan akhir lainnya, (9) Permintaan margin, (10) Harga di tingkat pembeli, (11) Kondisi keseimbangan pasar, (12) Pajak tidak langsung, (13) Produk Domestik Bruto dari sisi pendapatan dan pengeluaran, (14) Keseimbangan perdagangan dan agregasi lainnya, (15) Tingkat pengembalian, (16) Persamaan investasi-modal akumulasi, dan (17) Akumulasi hutang.

Emisi karbon dihitung di luar model INDOF berdasarkan konversi besar output per sektor. Rodriguez (2009) menghitung emisi karbon menggunakan elastisitas Armington dan elastisitas transformasi sebesar 1.256.34 sebagaimana penelitian Cororaton dan Corong (2006).

\section{KONSTRUKSI DATA DASAR}

\subsection{Disagregasi Sektor}

Tabel I-O tahun 2008 dilakukan disagregasi dari 66 menjadi 68 sektor
(Lampiran 2) menggunakan metode matrik disagregasi (Gambar 3). Disagregasi dilakukan secara bertahap. Setelah disagregasi per kolom semua telah selesai dilakukan, kemudian dilakukan disagregasi per baris. Sektor ubi kayu diperoleh dari disagregasi sektor tanaman umbi-umbian dengan pangsa sebesar 46.35 persen (BPS, 2008). Sektor BBN diperoleh dari disagregasi sektor pengilangan minyak bumi dengan pangsa sebesar 1.1 persen (Kementerian ESDM, 2011). BBN merupakan sebagian produksi yang berasal dari industri minyak dan lemak dengan pangsa sebesar 15 persen. Sektor industri minyak dan lemak antara lain berasal dari sektor-sektor kelapa sawit, ubi kayu, dan industri gula (molasses) dengan pangsa sebesar 10 persen (biosolar), serta 5 persen dan 10 persen untuk biopremium dan biopertamax.

\subsection{Konstruksi Data Dasar Lainnya}

Penerimaan pajak tidak langsung domestik dari setiap pengguna per komoditi dihitung dari nilai komoditi domestik per komoditi oleh pengguna (sektor 180) dikalikan rasio pajak tidak langsung (sektor 204) per komoditi dibagi jumlah input per komoditi oleh semua pengguna (sektor 210) (Oktaviani, 2000). Penerimaan pajak penjualan impor dari pengguna per komoditi dihitung dari nilai komoditi impor oleh pengguna (sektor 409) dikalikan rasio pajak penjualan per komoditi oleh semua pengguna (sektor 402) dibagi nilai impor pajak per komoditi oleh semua pengguna (sektor 401 dan 404) (Oktaviani, 2000). Investasi setiap industri dihitung menggunakan pangsa investasi per sektor, yaitu rasio jumlah nilai penerimaan modal (sektor 303) terhadap nilai penerimaan modal setiap industri per sektor (Oktaviani, 2000). Stok 
modal awal setiap industri dihitung dari rasio nilai penyusutan (sektor 203) terhadap tingkat penyusutan (Oktaviani, 2000).

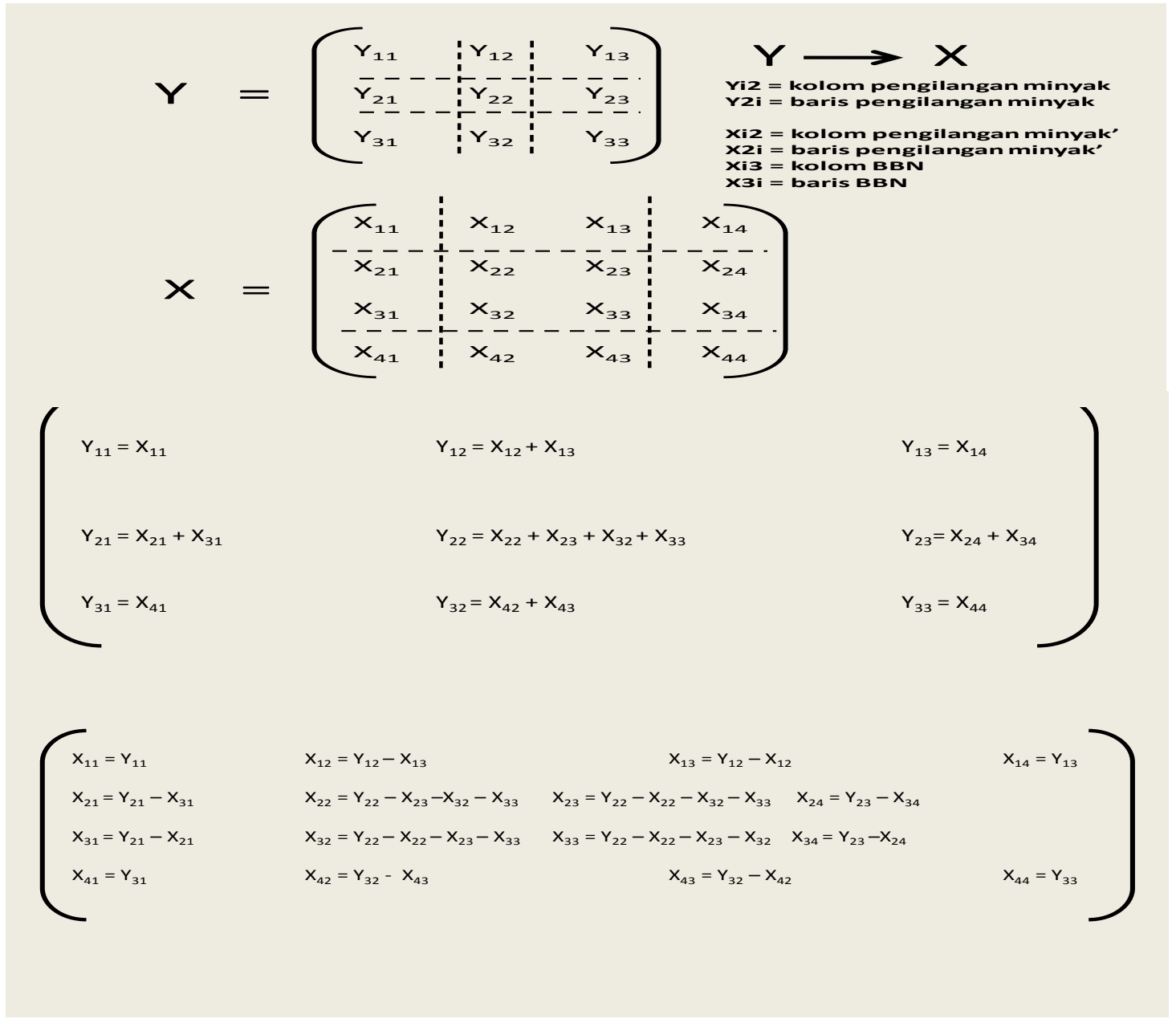

Gambar 3. Metoda Disagregasi

Rumah tangga didisagregasikan ke dalam 10 kelompok menggunakan data Tabel SNSE tahun 2005, yaitu: (1) Rumah tangga buruh pertanian, (2) Rumah tangga pengusaha pertanian memiliki tanah 0 ha -0.5 ha, (3) Rumah tangga pengusaha pertanian memiliki tanah 0.5 ha - 1.0 ha, (4) Rumah tangga pengusaha pertanian memiliki tanah 1 ha lebih, (5) Rumah tangga pengusaha bebas golongan rendah, tenaga tatausaha, pedagang keliling, pekerja bebas sektor angkutan, jasa perorangan, buruh kasar bukan pertanian di pedesaan, (6) Rumah tangga bukan angkatan kerja dan golongan tidak jelas bukan pertanian di pedesaan, (7) Rumah tangga pengusaha bebas golongan atas, pengusaha bukan pertanian, manajer, militer, profesional, teknisi, guru, pekerja tatausaha dan penjualan golongan atas bukan pertanian di pedesaan, (8) Rumah tangga pengusaha bebas golongan rendah, tenaga tatausaha, pedagang keliling, pekerja bebas sektor angkutan, jasa perorangan, buruh kasar bukan pertanian di perkotaan, (9) Rumah tangga bukan angkatan kerja dan golongan tidak jelas bukan pertanian di perkotaan, dan (10) Rumah tangga Pengusaha bebas golongan atas, pengusaha bukan 
pertanian, manajer, militer, profesional, teknisi, guru, pekerja tatausaha dan penjualan golongan atas bukan pertanian di perkotaan.

Jenis pekerjaan didisagregasikan ke sektor pertanian, operator, administrasi, dan profesional menggunakan data Tabel SNSE tahun 2005. Penerimaan modal dan lahan per individu dibangun dari jumlah surplus usaha (sektor 202) dan penyusutan (sektor 203). Sebanyak 80 persen dari jumlah surplus usaha dan penyusutan dialokasikan untuk penerimaan lahan. Sebanyak 20 persen dari jumlah surplus usaha dan penyusutan dialokasikan untuk penerimaan modal sektor pertanian. Komposisi penerimaan lahan dan modal sektor kehutanan dan pertambangan berbanding antara 85 persen dan 15 persen serta 75 persen dan 25 persen (Oktaviani, 2000). Tabel SNSE membedakan tenaga kerja penerima upah dan gaji maupun tenaga kerja bukan penerima upah dan gaji. Data total tenaga kerja penerima upah dan gaji (sektor 201) dikelompokkan sebagai data upah tenaga kerja. Data total tenaga kerja bukan penerima upah dan gaji ditransformasikan untuk menambah penerimaan modal dan lahan dengan proporsi 40 persen untuk menambah penerimaan modal dan sebanyak 60 persen untuk menambah penerimaan lahan.

\subsection{Koefisien Elastisitas dan}

\section{Parameter Lain}

Elastisitas Armington untuk intermediate, investasi, dan rumah tangga sebesar 1.3-11.2. Elastisitas substitusi faktor primer sebesar 0.5, elastisitas substitusi tenaga kerja bernilai sebesar 0.07-0.50, elastisitas transformasi sebesar 0 , elastisitas permintaan ekspor tradisional bernilai sebesar -2.23 hingga -9.98 , elastisitas permintaan ekspor non tradisional sebesar -4, elastisitas pengeluaran rumah tangga per kelompok rumah tangga sekitar 0.96, elastisitas upah tenaga kerja sebesar 0.5 , dan nilai trend tenaga kerja sebesar 1. Tingkat depresiasi sebesar 10 persen. Nilai trend investasi sebesar 0.10 dan dan nilai rasio investasi terhadap modal sebesar 5 . Parameter Frisch adalah rasio jumlah permintaan rumah tangga terhadap barang mewah. Parameter Frisch bernilai sebesar -2 hingga -4. Rasio investasi terhadap modal sebesar 0.117.

\subsection{Simulasi}

Simulasi pada penelitian ini adalah sebagai berikut:

1. Konsumsi BBN dari industri minyak dan lemak meningkat sebesar 5\%.

2. Perluasan lahan kelapa sawit meningkat sebesar 15\%, tebu meningkat sebesar 10\%, ubikayu meningkat sebesar 10\%, kayu menurun sebesar $25 \%$, dan hasil hutan lain menurun $25 \%$ dari ratarata perubahan lahan tersebut di pedesaan selama tahun 2000-2009, serta modal tetap industri minyak dan lemak maupun BBN Urban 3 meningkat masing-masing meningkat sebesar $10 \%$.

3. Produktivitas tanaman ubikayu menurun sebesar $10 \%$, tebu menurun sebesar $10 \%$, kelapa sawit tetap, industri minyak dan lemak meningkat sebesar $10 \%$, industri gula menurun sebesar $10 \%$, dan BBN meningkat sebesar $15 \%$.

\section{HASIL DAN PEMBAHASAN}

\subsection{Estimasi Baseline}

Pada konstruksi data dasar telah dicapai keseimbangan antara data pendapatan dan data pengeluaran (Tabel 1). Karena data telah seimbang, maka hasil konstruksi data dasar dapat digunakan untuk melakukan pengolahan data. 
Tabel 1. Keseimbangan Pendapatan dan Pengeluaran PDB

\begin{tabular}{|l|r|l|r|}
\hline \multicolumn{1}{|c|}{ Pendapatan } & \multicolumn{1}{c|}{ Rp Miliar } & \multicolumn{1}{c|}{ Pengeluaran } & \multicolumn{1}{c|}{ Rp Miliar } \\
\hline Lahan & 315079 & Konsumsi rumah tangga & 3195805 \\
\hline Tenaga kerja & 953952 & Investasi & 1405455 \\
\hline Modal & 3925358 & Pengeluaran pemerintah & 416867 \\
\hline Biaya lainnya & -196549 & Stok & 106326 \\
\hline Pajak tidak langsung & 266281 & Ekspor barang dan jasa & 1487238 \\
\hline & & Impor barang dan jasa & -1347570 \\
\hline Jumlah & 5264121 & Jumlah & 5264121 \\
\hline
\end{tabular}

Baseline pada Tabel 2 dipilih menggunakan metoda perbedaan kuadrat terkecil dari hasil estimasi dengan data aktual. Baseline berisi closure dan produktivitas sektoral. Estimasi pertumbuhan kumulatif impor barang dan jasa lebih rendah dibandingkan data aktual, karena rasio ekspor terhadap impor pada Tabel I-O tahun 2008 sebesar 110.36 persen, sedangkan berdasarkan data PDB menurut penggunaan sebesar 123.87 persen, dan berdasarkan data PDB menurut jenis pengeluaran Q4 sebesar 129.47 persen. Karena hasil estimasi Tabel 2 relatif telah mendekati data aktual, maka model dapat digunakan untuk updating dan dilanjutkan untuk melakukan analisis kebijakan mandat konsumsi BBN.

Tabel 2. Perbandingan Data Aktual dan Estimasi pada Indikator Ekonomi Makro di Indonesia Tahun 2008-2010

\begin{tabular}{|c|c|c|c|c|c|}
\hline \multirow[t]{2}{*}{$\begin{array}{l}\text { Indikator Ekonomi } \\
\text { Makro }\end{array}$} & \multicolumn{3}{|c|}{$\begin{array}{l}\text { Harga Konstan Tahun } 2000 *) \\
\text { (Rp Miliar) }\end{array}$} & \multicolumn{2}{|c|}{$\begin{array}{c}\text { Kumulatif } \\
\text { Tahun 2008-2010 } \\
\text { Q4 ke Q4 }(\%)\end{array}$} \\
\hline & 2008 & 2009 & 2010 & Aktual**) & Estimasi \\
\hline Produk Domestik Bruto & 2082456.1 & 2177741.7 & 2310689.8 & 12.28 & 12.20 \\
\hline Konsumsi rumah tangga & 1191190.8 & 1249011.2 & 1306800.9 & 8.40 & 5.76 \\
\hline Investasi & 493822.3 & 510100.2 & 553444.3 & 12.80 & 10.16 \\
\hline Pengeluaran pemerintah & 169297.2 & 195834.4 & 196397.6 & 25.33 & 25.33 \\
\hline Ekspor barang dan jasa & 1032277.8 & 932248.6 & 1071385.3 & 19.84 & 17.75 \\
\hline Impor barang dan jasa & 833342.2 & 708528.8 & 830981.8 & 18.51 & 6.11 \\
\hline
\end{tabular}

Sumber: *) www.bps.go.id, $\left.{ }^{* *}\right)$ www.bi.go.id

\subsection{Dampak Implementasi Mandat Konsumsi BBN}

Sim 1, 2, dan 3 berdampak positif pada perekonomian nasional berupa peningkatan neraca perdagangan per PDB, peningkatan pembayaran modal agregat, peningkatan pembayaran tenaga kerja agregat, peningkatan pertumbuhan ekonomi, dan peningkatan ekspor (Tabel 3). Temuan peningkatan pertumbuhan ekonomi menunjukkan bahwa mandat konsumsi $\mathrm{BBN}$ bersifat pro-growth. 
Tabel 3. Dampak Implementasi Mandat Konsumsi BBN terhadap Keragaan Ekonomi Makro di Indonesia Tahun 2015

Persentase Perubahan (\%)

\begin{tabular}{|l|r|r|r|r|}
\hline \multicolumn{1}{|c|}{ Indikator Ekonomi Makro } & Baseline & \multicolumn{1}{c|}{ Sim 1 } & \multicolumn{1}{c|}{ Sim 2 } & \multicolumn{1}{c|}{ Sim 3 } \\
\hline Neraca perdagangan per PDB & 2.35 & 2.97 & 2.37 & 2.38 \\
\hline Sewa modal pertanian nasional & 24.79 & 25.81 & 24.82 & 25.06 \\
\hline Sewa modal non pertanian nasional & 34.21 & 34.31 & 34.22 & 34.18 \\
\hline Indeks harga konsumen & 19.94 & 20.07 & 19.95 & 19.97 \\
\hline Upah riil rata-rata & 16.14 & 16.71 & 16.17 & 16.10 \\
\hline Pembayaran modal agregat & 31.14 & 31.72 & 31.16 & 31.14 \\
\hline Pembayaran tenaga kerja agregat & 36.08 & 36.78 & 36.12 & 36.08 \\
\hline Pembayaran lahan agregat & 23.03 & 24.05 & 22.93 & 23.30 \\
\hline PDB riil dari sisi pengeluaran & 12.20 & 12.85 & 12.22 & 12.22 \\
\hline Indeks volume impor & 6.11 & 6.03 & 6.11 & 6.12 \\
\hline Pengeluaran investasi riil agregat & 10.16 & 10.03 & 10.15 & 10.13 \\
\hline Konsumsi rumah tangga riil & 5.76 & 5.63 & 5.75 & 5.73 \\
\hline Indeks volume ekspor & 17.75 & 20.39 & 17.85 & 17.90 \\
\hline Permintaan pemerintah riil agregat & 25.33 & 25.33 & 25.33 & 25.33 \\
\hline Inventori riil agregat & 29.89 & 29.78 & 29.99 & 30.02 \\
\hline
\end{tabular}

Sim 1, 2, dan 3 berdampak negatif berupa peningkatan sewa modal pertanian, peningkatan indeks harga konsumen, dan penurunan konsumsi rumah tangga riil. Sim 1 dan 2 berdampak negatif berupa peningkatan sewa modal non pertanian nasional dan upah riil rata-rata, namun $\operatorname{Sim} 3$ berdampak positif berupa penurunan sewa modal non pertanian nasional dan penurunan upah riil rata-rata. Sim 1 dan 3 berdampak positif berupa peningkatan pembayaran lahan agregat, namun Sim 2 berdampak negatif berupa penurunan pembayaran lahan agregat. Sim 2 dan 3 berdampak negatif berupa peningkatan impor dan berdampak positif berupa peningkatan inventori riil agregat, namun Sim 1 berdampak positif berupa penurunan impor dan berdampak negatif berupa penurunan inventori riil agregat.

Sim 1, 2, dan 3 berdampak positif berupa peningkatan output pada sektor BBN, kelapa sawit, dan industri minyak dan lemak, namun berdampak negatif berupa penurunan output sektor padi, kayu, hasil hutan lain, industri pengolahan dan pengawetan makanan, industri penggilingan padi, industri tepung, dan industri makanan lainnya (Tabel 4). Penurunan output sektorsektor tersebut, meskipun terjadi peningkatan harga output harga impor tetap, namun jumlah penawaran impor sektor tersebut mengalami peningkatan.

Tabel 4. Dampak Implementasi Mandat Konsumsi BBN terhadap Output Sektor Tanaman Pangan, Tanaman Pakan, Kehutanan, Industri Makanan, dan Transportasi di Indonesia Tahun 2015

Persentase Perubahan (\%)

\begin{tabular}{|l|l|r|r|r|r|}
\hline Kelompok & Sektor & Baseline & Sim 1 & Sim 2 & \multicolumn{1}{c|}{ Sim 3 } \\
\hline \multirow{2}{*}{$\begin{array}{l}\text { Tanaman } \\
\text { Pangan }\end{array}$} & Padi & 7.21 & 6.99 & 7.19 & 7.16 \\
\cline { 2 - 6 } & Tebu & 11.47 & 11.77 & 11.59 & 11.01 \\
\cline { 2 - 7 }
\end{tabular}




\begin{tabular}{|l|l|r|r|r|r|}
\hline Kelompok & \multicolumn{1}{|c|}{ Sektor } & Baseline & Sim 1 & \multicolumn{1}{c|}{ Sim 2 } & \multicolumn{1}{c|}{ Sim 3 } \\
\hline & Kelapa sawit & 12.31 & 17.27 & 13.13 & 13.28 \\
\hline \multirow{2}{*}{$\begin{array}{l}\text { Tanaman } \\
\text { Pakan }\end{array}$} & Jagung & 8.21 & 8.06 & 8.21 & 8.16 \\
\cline { 2 - 6 } Kehutanan & Ubi kayu & 8.09 & 7.83 & 8.13 & 7.67 \\
\cline { 2 - 6 } & Kayu & 6.92 & 6.77 & 6.91 & 6.90 \\
\cline { 2 - 6 } $\begin{array}{l}\text { Industri } \\
\text { makanan }\end{array}$ & Industri pengolahan dan & 6.92 & 6.62 & 6.88 & 6.87 \\
\cline { 2 - 6 } & pengawetan makanan & & & & \\
\cline { 2 - 6 } & Industri minyak dan lemak & 10.44 & 33.77 & 11.44 & 11.73 \\
\cline { 2 - 6 } & Industri penggilingan padi & 7.15 & 6.94 & 7.14 & 7.10 \\
\cline { 2 - 6 } & Industri tepung, segala jenis & 6.62 & 6.45 & 6.61 & 6.58 \\
\cline { 2 - 6 } & Industri gula & 11.57 & 11.20 & 11.60 & 10.90 \\
\cline { 2 - 6 } & Industri makanan lainnya & 8.52 & 8.36 & 8.51 & 8.47 \\
\hline Pengilangan & minyak bumi & -6.74 & -6.84 & -6.75 & -6.72 \\
\hline Bahan bakar nabati & 12.63 & 15.44 & 13.21 & 13.16 \\
\hline \multirow{4}{*}{ Transportasi } & Angkutan kereta api & 6.95 & 6.78 & 6.94 & 6.95 \\
\cline { 2 - 6 } & Angkutan darat & 11.48 & 11.35 & 11.47 & 11.49 \\
\cline { 2 - 6 } & Angkutan air & 20.40 & 20.24 & 20.39 & 20.40 \\
\cline { 2 - 6 } & Angkutan udara & & & & \\
\hline
\end{tabular}

Keterangan:

Sim 1: Baseline + konsumsi BBN dari industri minyak dan lemak meningkat.

Sim 2: Baseline + perluasan lahan kelapa sawit, tebu, dan ubikayu meningkat, luas lahan kayu dan hasil hutan lain menurun, modal tetap industri minyak dan lemak maupun BBN Urban 3 meningkat.

Sim 3: Baseline + perubahan produktivitas tanaman kelapa sawit, tebu, ubikayu, industri minyak dan lemak, serta BBN.

Output sektor tebu meningkat pada Sim 1 dan 2, namun output tebu menurun pada Sim 3 disebabkan oleh jumlah penawaran impor tebu yang meningkat, meskipun harga output tebu pada Sim 3 meningkat dan harga impor tebu tetap. Output jagung dan ubi kayu, serta industri gula menurun pada Sim 1 dan 3, karena jumlah penawaran impor sektor-sektor tersebut meningkat, meskipun harga output sektor tersebut meningkat dan harga impornya meningkat. Output sektor pengilangan minyak bumi, angkutan kereta api, angkutan darat, angkutan air, dan angkutan udara menurun pada Sim 1 dan 2, namun output sektor-sektor tersebut meningkat pada Sim 3 . Penurunan output sektor pengilangan minyak bumi, angkutan kereta api, angkutan darat, angkutan air, dan angkutan udara pada Sim 1 dan 2, karena jumlah penawaran impor sektorsektor tersebut meningkat, meskipun harga output meningkat dan harga impornya tetap. Karena itu, penurunan output sektor-sektor tertentu pada Sim 1, 2 , dan 3 terkait dengan pemberlakuan kebijakan impor untuk menekan peningkatan harga output yang lebih berpihak kepada kepentingan konsumen dan pemilik modal dibandingkan petani produsen dan pekerja. 
Tabel 5. Dampak Implementasi Mandat Konsumsi BBN terhadap Permintaan Tenaga Kerja oleh Industri di Indonesia Tahun 2015

Persentase Perubahan (\%)

\begin{tabular}{|l|r|r|r|r|}
\hline \multicolumn{1}{|c|}{ Sektor } & \multicolumn{1}{c|}{ Baseline } & \multicolumn{1}{c|}{ Sim 1 } & \multicolumn{1}{c|}{ Sim 2 } & \multicolumn{1}{c|}{ Sim 3 } \\
\hline Padi & -2.34 & -2.88 & -2.36 & -2.47 \\
\hline Jagung & -0.93 & -1.35 & -0.92 & -1.05 \\
\hline Ubi kayu & -1.08 & -1.67 & -1.16 & -0.37 \\
\hline Tebu & -5.96 & -5.73 & -5.96 & -4.48 \\
\hline Kelapa & -6.65 & -3.66 & -6.13 & -6.11 \\
\hline Kelapa sawit & -4.52 & 2.11 & -4.43 & -3.24 \\
\hline Tembakau & -12.14 & -12.63 & -12.16 & -12.24 \\
\hline Kopi & 7.90 & 6.88 & 7.87 & 7.65 \\
\hline Teh & -8.25 & -8.73 & -8.26 & -8.37 \\
\hline Cengkeh & -9.08 & -9.68 & -9.10 & -9.19 \\
\hline Industri minyak dan lemak & 13.10 & 34.74 & 14.22 & 13.07 \\
\hline Bahan bakar nabati & 18.25 & 23.04 & 18.54 & 18.70 \\
\hline
\end{tabular}

Keterangan:

Sim 1: Baseline + konsumsi BBN dari industri minyak dan lemak meningkat.

Sim 2: Baseline + perluasan lahan kelapa sawit, tebu, dan ubikayu meningkat, luas lahan kayu dan hasil hutan lain menurun, modal tetap industri minyak dan lemak maupun BBN Urban 3 meningkat.

Sim 3: Baseline + perubahan produktivitas tanaman kelapa sawit, tebu, ubikayu, industri minyak dan lemak, serta BBN.

Sim 1, 2, dan 3 berdampak positif pada peningkatan permintaan tenaga kerja sektor $\mathrm{BBN}$, industri minyak dan lemak, tebu, kelapa, dan kelapa sawit (Tabel 5), meskipun terjadi peningkatan upah tenaga kerjanya, namun Sim 1, 2, dan 3 berdampak negatif berupa penurunan tenaga kerja pada sektor padi, tembakau, kopi, teh, dan cengkeh, karena peningkatan upah pada sektorsektor tersebut ketika terjadi penurunan output dan peningkatan jumlah impor, meskipun terjadi peningkatan harga output. Sim 1 dan 3 berdampak negatif berupa penurunan permintaan tenaga kerja pada sektor jagung, karena peningkatan upah tenaga kerja pada sektor pertanian ketika terjadi penurunan output dan peningkatan jumlah impor, meskipun terjadi peningkatan harga output, namun Sim 2, yaitu perluasan lahan tanaman BBN, penurunan luas lahan sektor kayu dan hasil hutan lain, serta peningkatan modal tetap pada industri minyak dan lemak dan BBN Urban 3 berdampak positif berupa peningkatan permintaan tenaga kerja pada sektor jagung, meskipun terjadi peningkatan upah tenaga kerja pada sektor jagung. Temuan ini menunjukkan bahwa mandat konsumsi BBN bersifat pro-jobs pada sektor tanaman $\mathrm{BBN}$, industri minyak dan lemak, serta BBN, namun diikuti penurunan permintaan tenaga kerja pada sektor pertanian non BBN ketika jumlah ouputnya mengalami penurunan, terjadi peningkatan upah tenaga kerja, dan peningkatan jumlah impor, meskipun harga output mengalami peningkatan. 
Tabel 6. Dampak Implementasi Mandat Konsumsi BBN terhadap Konsumsi Beras Domestik dan Pendapatan yang Diterima Rumah Tangga Nominal Agregat Berdasarkan Kelompok Rumah Tangga di Indonesia Tahun 2015

Persentase Perubahan (\%)

\begin{tabular}{|l|r|r|r|r|r|r|r|r|}
\hline \multirow{2}{*}{$\begin{array}{c}\text { Kelompok } \\
\text { Rumah } \\
\text { Tangga }\end{array}$} & \multicolumn{4}{|c|}{ Konsumsi Beras Domestik } & \multicolumn{4}{|c|}{$\begin{array}{c}\text { Pendapatan yang Diterima Rumah } \\
\text { Tangga Nominal Agregat }\end{array}$} \\
\cline { 2 - 10 } & Baseline & Sim 1 & Sim 2 & Sim 3 & Baseline & Sim 1 & Sim 2 & Sim 3 \\
\hline Rural 1 & 4.69 & 4.51 & 4.68 & 4.65 & 32.69 & 33.35 & 32.72 & 32.72 \\
\hline Rural 2 & 5.20 & 5.02 & 5.20 & 5.16 & 33.20 & 33.88 & 33.23 & 33.22 \\
\hline Rural 3 & 4.81 & 4.60 & 4.80 & 4.76 & 32.55 & 33.22 & 32.59 & 32.58 \\
\hline Rural 4 & 4.79 & 4.54 & 4.78 & 4.73 & 32.34 & 33.00 & 32.38 & 32.36 \\
\hline Rural 5 & 5.47 & 5.32 & 5.46 & 5.44 & 33.61 & 34.31 & 33.64 & 33.64 \\
\hline Rural 6 & 4.58 & 4.37 & 4.56 & 4.53 & 32.35 & 33.01 & 32.37 & 32.37 \\
\hline Rural 7 & 5.56 & 5.34 & 5.54 & 5.51 & 33.29 & 34.00 & 33.31 & 33.32 \\
\hline Urban 1 & 8.51 & 8.26 & 8.50 & 8.46 & 33.76 & 34.47 & 33.79 & 33.79 \\
\hline Urban 2 & 7.21 & 6.90 & 7.18 & 7.14 & 32.58 & 33.26 & 32.59 & 32.61 \\
\hline Urban 3 & 8.68 & 8.36 & 8.67 & 8.61 & 33.61 & 34.33 & 33.65 & 33.65 \\
\hline
\end{tabular}

Keterangan:

Sim 1: Baseline + konsumsi BBN dari industri minyak dan lemak meningkat.

Sim 2: Baseline + perluasan lahan kelapa sawit, tebu, dan ubikayu meningkat, luas lahan kayu dan hasil hutan lain menurun, modal tetap industri minyak dan lemak maupun BBN Urban 3 meningkat.

Sim 3: Baseline + perubahan produktivitas tanaman kelapa sawit, tebu, ubikayu, industri minyak dan lemak, serta BBN.

Ketahanan pangan didefinisikan sebagai kondisi terpenuhinya kebutuhan pangan bagi rumah tangga yang tercermin dari tersedianya pangan secara cukup, baik dari jumlah maupun mutunya, aman, merata dan terjangkau. Dari jumlah konsumsi nominal setiap rumah tangga dapat diperoleh permintaan dasar setiap rumah tangga untuk sektor industri penggilingan padi (beras). Keberadaan perubahan konsumsi beras dan outputnya diperlukan untuk menganalisis keberadaan ketahanan pangan tingkat rumah tangga. Sim 1, 2, dan 3 berdampak negatif berupa penurunan konsumsi beras bersumber domestik pada semua kelompok rumah tangga (Tabel 6) dan terjadi penurunan output sektor padi dan industri penggilingan padi (Tabel 4). Temuan tersebut menunjukkan bahwa mandat konsumsi BBN di Indonesia bersifat paradoks terhadap ketahanan pangan (beras) sebagaimana kekhawatiran Ziegler (2008) dan FAO (2008).

Sim 1, 2, dan 3 berdampak positif pada pendapatan yang diterima rumah tangga nominal agregat (Tabel 6). SNSE non finansial tidak membedakan kelompok rumah tangga miskin dan bukan miskin, sehingga peningkatan pendapatan yang diterima rumah tangga nominal agregat pada semua kelompok rumah tangga tersebut tidak serta merta dinyatakan bahwa mandat konsumsi BBN bersifat pro-poor.

Sim 1, 2, dan 3 berdampak positif berupa penurunan TDS, PM, SOX, NOX, VOC, dan CO pada sektor BBN, serta berdampak negatif pada sektor pengilangan minyak bumi (Tabel 7). Temuan ini menunjukkan bahwa mandat konsumsi BBN bersifat proenvironment dan tidak sesuai dengan kekhawatiran Beeman (2007). 
Tabel 7. Dampak Implementasi Mandat Konsumsi BBN terhadap Emisi Karbon Sektor Pengilangan Minyak Bumi dan BBN di Indonesia Tahun 2015

Persentase Perubahan $(\%)$

\begin{tabular}{|c|c|c|c|c|c|}
\hline Emisi Karbon & Sektor & Baseline & Sim 1 & $\operatorname{Sim} 2$ & $\operatorname{Sim} 3$ \\
\hline \multirow{2}{*}{$\begin{array}{l}\text { Total suspended } \\
\text { solid (TDS) }\end{array}$} & Pengilangan minyak bumi & 0.07 & 0.07 & 0.07 & 0.07 \\
\hline & Bahan bakar nabati & -0.38 & -0.46 & -0.40 & -0.39 \\
\hline \multirow{2}{*}{$\begin{array}{l}\text { Particular matter } \\
(\mathrm{PM})\end{array}$} & Pengilangan minyak bumi & 0.27 & 0.27 & 0.27 & 0.27 \\
\hline & Bahan bakar nabati & -0.51 & -0.62 & -0.53 & -0.53 \\
\hline \multirow[t]{2}{*}{ Sulfur oxide (SOX) } & Pengilangan minyak bumi & 0.54 & 0.55 & 0.54 & 0.54 \\
\hline & Bahan bakar nabati & -1.01 & -1.24 & -1.06 & -1.05 \\
\hline \multirow{2}{*}{$\begin{array}{l}\text { Nitrogen oxide } \\
\text { (NOX) }\end{array}$} & Pengilangan minyak bumi & 0.40 & 0.41 & 0.41 & 0.40 \\
\hline & Bahan bakar nabati & -0.76 & -0.93 & -0.79 & -0.79 \\
\hline \multirow{2}{*}{$\begin{array}{l}\text { Volatile organic } \\
\text { compounds (VOC) }\end{array}$} & Pengilangan minyak bumi & 0.27 & 0.27 & 0.27 & 0.27 \\
\hline & Bahan bakar nabati & -0.51 & -0.62 & -0.53 & -0.53 \\
\hline \multirow{2}{*}{$\begin{array}{l}\text { Carbon monoxide } \\
\text { (CO) }\end{array}$} & Pengilangan minyak bumi & 0.27 & 0.27 & 0.27 & 0.27 \\
\hline & Bahan bakar nabati & -0.51 & -0.62 & -0.53 & -0.53 \\
\hline
\end{tabular}

Keterangan:

Sim 1: Baseline + konsumsi BBN dari industri minyak dan lemak meningkat.

Sim 2: Baseline + perluasan lahan kelapa sawit, tebu, dan ubikayu meningkat, luas lahan kayu dan hasil hutan lain menurun, modal tetap industri minyak dan lemak maupun BBN Urban 3 meningkat.

Sim 3: Baseline + perubahan produktivitas tanaman kelapa sawit, tebu, ubikayu, industri minyak dan lemak, serta BBN.

\section{KESIMPULAN DAN IMPLIKASI KEBIJAKAN}

\subsection{Kesimpulan}

Berdasarkan

pembahasan di atas, maka disusun kesimpulan bahwa implementasi kebijakan mandat konsumsi BBN melalui peningkatan konsumsi $\mathrm{BBN}$, perubahan luas lahan dan peningkatan modal tetap sektor industri minyak dan lemak serta BBN Urban 3, maupun perubahan produktivitas berdampak efektif untuk peningkatan pertumbuhan ekonomi, peningkatan pendapatan yang diterima semua rumah tangga nominal agregat, peningkatan permintaan tenaga kerja pada tanaman bahan baku BBN, dan penurunan emisi karbon (proenvironment). Akan tetapi kebijakan mandat konsumsi BBN tersebut bersifat kontraproduktif terhadap ketahanan pangan, menurunkan output pakan, dan menurunkan permintaan tenaga kerja non $\mathrm{BBN}$, dimana pemerintah lebih berpihak kepada kepentingan konsumen dan pemilik modal dibandingkan produsen dan pekerja dengan memberlakukan impor ketika terjadi penurunan output dan menekan peningkatan harga output dan peningkatan upah tenaga untuk menahan peningkatan laju inflasi.

\subsection{Implikasi Kebijakan}

Berdasarkan kesimpulan di atas, maka implikasi kebijakannya adalah kebijakan mandat konsumsi BBN perlu diikuti peningkatan output tanaman non BBN melalui peningkatan produktivitas tanaman non BBN dan kebijakan impor pangan yang memperhatikan peningkatan kesejahteraan petani dan pekerja pangan. 


\section{DAFTAR PUSTAKA}

Badan Pusat Statistik [BPS]. 2008. Sistem Neraca Sosial Ekonomi Indonesia 2005. Badan Pusat Statistik, Jakarta.

2009.

Tabel Input Output Indonesia UpDating 2008. Badan Pusat Statistik, Jakarta.

Beeman, P. 2007. Biofuel Plants Generate Environmental Problems in Iowa. The Bioenergy Blog, 3 June 2007. Retrieved on 1 March 2008 from http:/bioeconomyblog.blogspot.c om/2007/06/dm-register-biofuelplantsgenerate. html.

Cororaton, C. and E. Corong. 2006. Agriculture-Sector Policies and Poverty in the Philippines: a Computable GeneralEquilibrium (CGE) Analysis. MPIA Working Paper 2006-19, Poverty and Economic Policy Research Network.

Departemen Energi dan Sumberdaya Manusia Republik Indonesia [Departemen ESDM RI]. 2008. Timnas BBN Gelar Workshop Sosialisasi Pengembangan Bahan Bakar Nabati (BBN). Departemen Energi dan Sumberdaya Manusia, Jakarta.

Kementerian Energi dan Sumberdaya Manusia [Kementerian ESDM]. 2011. Statistik Energi Baru terbarukan. Kementerian Energi dan Sumberdaya Manusia, Jakarta.

Dillon, H.S., T. Laan, and H.S. Dillon. 2008. Biofuels-At What Cost? Government Support for Ethanol and Biodiesel in Indonesia: One of a Series of Reports Addressing Subsidies for Biofuels in Developing Countries. The Global Subsidies
Initiative of the International Institute for Sustainable Development, Jakarta.

Food and Agriculture Organization [FAO]. 2008. Biofuels: Prospect, Risks, and Opportunities. Food and Agriculture Organization of the United Nations, Rome.

Horridge, J.M, B.R. Parmenter and KR. Pearson. 1993. ORANI-F: A General Equilibrium Model of the Australian Economy. Economic and Financial Computing, 3:71-140.

Koh, L.P. and D.S. Wilcove. 2007. Cashing in Palm Oil for Conservation. Nature (448): 993-994.

Oktaviani, R. 2000. The Impact of APEC Trade Liberalisation on Indonesian Economy and Its Agricultural Sector. Thesis of Doctor of Philosophy. Department of Agricultural Economics, University of Sydney, Sydney.

Oktaviani, R. 2008. Model Ekonomi Keseimbangan Umum: Teori dan Aplikasinya di Indonesia. Departemen llmu Ekonomi, Fakultas Ekonomi dan Manajemen, Institut Pertanian Bogor, Bogor.

Park, J. 2010. Projection of Long-Term Total Factor Productivity Growth for 12 Asian Economies. Working Paper Series no. 227. Asian Development Bank, Manila.

Rodriguez, U.E. 2009. Biofuel and the Environment: An Analysis Using A Computable General Equilibrium Model the Philippines. Working Paper No.2009-15. CEM Working Paper Series. College of Economics and Management University of the Philippines Los Banos, Laguna. 
Sekretariat Kabinet [Setkab]. 2006. Instruksi Presiden Republik Indonesia Nomor 1 Tahun 2006 tentang Penyediaan dan Pemanfaatan Bahan Bakar Nabati (Biofuel) sebagai Bahan Bakar Lain. Sekretariat Negara Republik Indonesia, Jakarta. $2006 a$.

Peraturan Presiden Republik
Indonesia Nomor 5 Tahun 2006 tentang Kebijakan Energi Nasional. Sekretariat Negara Republik Indonesia, Jakarta.

Ziegler, J. 2008. Pejabat PBB Sebut Bahan Bakar Nabati "Kejahatan Atas Kemanusiaan". Green Press Network dalam Antara, 17 April 2008. 
Lampiran 1. Produktifitas TFP per sektor dalam Penelitian

\begin{tabular}{|c|c|c|c|}
\hline Sektor & $\begin{array}{l}\text { Produktivitas } \\
\text { (Persen) }\end{array}$ & Sektor & $\begin{array}{l}\text { Produktivitas } \\
\text { (Persen) }\end{array}$ \\
\hline Padi & 8.74 & Industri rokok & 6.52 \\
\hline Tanaman kacang-kacangan & 8.74 & Industri pemintalan & 3.29 \\
\hline Jagung & 8.74 & $\begin{array}{l}\text { Industri tekstil, pakaian dan } \\
\text { kulit }\end{array}$ & 3.29 \\
\hline Ubikayu & 8.74 & $\begin{array}{l}\text { Industri bambu, kayu dan } \\
\text { rotan }\end{array}$ & 0.15 \\
\hline Tanaman umbi-umbian & 8.74 & $\begin{array}{l}\text { Industri kertas, barang dari } \\
\text { kertas dan karton }\end{array}$ & 9.92 \\
\hline Sayur-sayuran dan buah-buahan & 8.74 & Industri pupuk dan pestisida & 15.71 \\
\hline Tanaman bahan makanan lainnya & 8.74 & Industri kimia & 15.71 \\
\hline Karet & 15.46 & Pengilangan minyak bumi & -3.0 \\
\hline Tebu & 15.46 & Bahan bakar nabati & 1.96 \\
\hline Kelapa & 15.46 & $\begin{array}{l}\text { Industri barang karet dan } \\
\text { plastik }\end{array}$ & 15.71 \\
\hline Kelapa sawit & 15.46 & $\begin{array}{l}\text { Industri barang-barang dari } \\
\text { mineral bukan logam }\end{array}$ & -7.48 \\
\hline Tembakau & 15.46 & Industri semen & 14.13 \\
\hline Kopi & 15.46 & Industri dasar besi dan baja & -1.10 \\
\hline Teh & 15.46 & $\begin{array}{l}\text { Industri logam dasar bukan } \\
\text { besi }\end{array}$ & -1.10 \\
\hline Cengkeh & 15.46 & Industri barang dari logam & -1.10 \\
\hline Hasil tanaman serat & 15.46 & $\begin{array}{l}\text { Industri mesin, alat-alat dan } \\
\text { perlengkapan listrik }\end{array}$ & 29.47 \\
\hline Tanaman perkebunan lainnya & 15.46 & $\begin{array}{l}\text { Industri alat pengangkutan } \\
\text { dan perbaikannya }\end{array}$ & 29.47 \\
\hline Tanaman lainnya & 15.46 & $\begin{array}{l}\text { Industri barang lain yang } \\
\text { belum digolongkan } \\
\text { dimanapun }\end{array}$ & 13.08 \\
\hline Peternakan & 9.2 & Listrik, gas dan air bersih & 13.41 \\
\hline Pemotongan hewan & 9.2 & Bangunan & 15.59 \\
\hline Unggas dan hasil-hasilnya & 9.2 & Perdagangan & 13.53 \\
\hline Kayu & 2.83 & Restoran dan hotel & 13.22 \\
\hline Hasil hutan lainnya & 9.73 & Angkutan kereta api & -1.34 \\
\hline Perikanan & 10.67 & Angkutan darat & 12.07 \\
\hline Penambangan batubara dan bijih logam & 18.69 & Angkutan air & 11.58 \\
\hline $\begin{array}{l}\text { Penambangan minyak, gas dan panas } \\
\text { bumi }\end{array}$ & -5.71 & Angkutan udara & 37.39 \\
\hline Penambangan dan penggalian lainnya & 15.64 & Jasa penunjang angkutan & 15.68 \\
\hline $\begin{array}{l}\text { Industri pengolahan dan pengawetan } \\
\text { makanan }\end{array}$ & 6.52 & Komunikasi & 48.54 \\
\hline Industri minyak dan lemak & 6.52 & Lembaga keuangan & 11.40 \\
\hline Industri penggilingan padi & 6.52 & $\begin{array}{l}\text { Real estat dan jasa } \\
\text { perusahaan }\end{array}$ & 19.14 \\
\hline Industri tepung, segala jenis & 6.52 & $\begin{array}{l}\text { Pemerintahan umum dan } \\
\text { pertahanan }\end{array}$ & 5.19 \\
\hline Industri gula & 6.52 & Jasa sosial kemasyarakatan & 16.35 \\
\hline Industri makanan lainnya & 6.52 & Jasa lainnya & 16.35 \\
\hline Industri minuman & 6.52 & $\begin{array}{l}\text { Kegiatan yang tidak jelas } \\
\text { batasannya }\end{array}$ & 16.35 \\
\hline
\end{tabular}


Lampiran 2. Disagregasi Sektor dalam Penelitian Berdasarkan Tabel IO Tahun 2008 Klasifikasi 66 Sektor ke 68 Sektor Penelitian

\begin{tabular}{|c|c|c|c|}
\hline No. & 66 Sektor Tabel IO Tahun 2008 & No. & 68 Sektor Penelitian \\
\hline 1 & Padi & 1 & Padi \\
\hline 2 & Tanaman kacang-kacangan & 2 & Tanaman kacang-kacangan \\
\hline 3 & Jagung & 3 & Jagung \\
\hline \multirow[t]{2}{*}{4} & \multirow[t]{2}{*}{ Tanaman umbi-umbian } & 4 & Ubikayu \\
\hline & & 5 & Tanaman umbi-umbian \\
\hline 5 & Sayur-sayuran dan buah-buahan & 6 & Sayur-sayuran dan buah-buahan \\
\hline 6 & Tanaman bahan makanan lainnya & 7 & Tanaman bahan makanan lainnya \\
\hline 7 & Karet & 8 & Karet \\
\hline 8 & Tebu & 9 & Tebu \\
\hline 9 & Kelapa & 10 & Kelapa \\
\hline 10 & Kelapa sawit & 11 & Kelapa sawit \\
\hline 11 & Tembakau & 12 & Tembakau \\
\hline 12 & Kopi & 13 & Kopi \\
\hline 13 & Teh & 14 & Teh \\
\hline 14 & Cengkeh & 15 & Cengkeh \\
\hline 15 & Hasil tanaman serat & 16 & Hasil tanaman serat \\
\hline 16 & Tanaman perkebunan lainnya & 17 & Tanaman perkebunan lainnya \\
\hline 17 & Tanaman lainnya & 18 & Tanaman lainnya \\
\hline 18 & Peternakan & 19 & Peternakan \\
\hline 19 & Pemotongan hewan & 20 & Pemotongan hewan \\
\hline 20 & Unggas dan hasil-hasilnya & 21 & Unggas dan hasil-hasilnya \\
\hline 21 & Kayu & 22 & Kayu \\
\hline 22 & Hasil hutan lainnya & 23 & Hasil hutan lainnya \\
\hline 23 & Perikanan & 24 & Perikanan \\
\hline 24 & $\begin{array}{l}\text { Penambangan batubara dan bijih } \\
\text { logam }\end{array}$ & 25 & $\begin{array}{l}\text { Penambangan batubara dan bijih } \\
\text { logam }\end{array}$ \\
\hline 25 & $\begin{array}{l}\text { Penambangan minyak, gas dan } \\
\text { panas bumi }\end{array}$ & 26 & $\begin{array}{l}\text { Penambangan minyak, gas dan panas } \\
\text { bumi }\end{array}$ \\
\hline 26 & $\begin{array}{l}\text { Penambangan dan penggalian } \\
\text { lainnya }\end{array}$ & 27 & Penambangan dan penggalian lainnya \\
\hline 27 & $\begin{array}{l}\text { Industri pengolahan dan } \\
\text { pengawetan makanan }\end{array}$ & 28 & $\begin{array}{l}\text { Industri pengolahan dan pengawetan } \\
\text { makanan }\end{array}$ \\
\hline 28 & Industri minyak dan lemak & 29 & Industri minyak dan lemak \\
\hline 29 & Industri penggilingan padi & 30 & Industri penggilingan padi \\
\hline 30 & Industri tepung, segala jenis & 31 & Industri tepung, segala jenis \\
\hline 31 & Industri gula & 32 & Industri gula \\
\hline 32 & Industri makanan lainnya & 33 & Industri makanan lainnya \\
\hline 33 & Industri minuman & 34 & Industri minuman \\
\hline 34 & Industri rokok & 35 & Industri rokok \\
\hline 35 & Industri pemintalan & 36 & Industri pemintalan \\
\hline
\end{tabular}


Lampiran 2. Lanjutan

\begin{tabular}{|c|c|c|c|}
\hline No. & 66 Sektor & No. & 68 Sektor \\
\hline 36 & Industri tekstil, pakaian dan kulit & 37 & Industri tekstil, pakaian dan kulit \\
\hline 37 & Industri bambu, kayu dan rotan & 38 & Industri bambu, kayu dan rotan \\
\hline 38 & $\begin{array}{l}\text { Industri kertas, barang dari kertas } \\
\text { dan karton }\end{array}$ & 39 & $\begin{array}{l}\text { Industri kertas, barang dari kertas dan } \\
\text { karton }\end{array}$ \\
\hline 39 & Industri pupuk dan pestisida & 40 & Industri pupuk dan pestisida \\
\hline 40 & Industri kimia & 41 & Industri kimia \\
\hline \multirow[t]{2}{*}{41} & \multirow[t]{2}{*}{ Pengilangan minyak bumi } & 42 & Pengilangan minyak bumi \\
\hline & & 43 & Bahan bakar nabati \\
\hline 42 & Industri barang karet dan plastik & 44 & Industri barang karet dan plastik \\
\hline 43 & $\begin{array}{l}\text { Industri barang-barang dari } \\
\text { mineral bukan logam }\end{array}$ & 45 & $\begin{array}{l}\text { Industri barang-barang dari mineral } \\
\text { bukan logam }\end{array}$ \\
\hline 44 & Industri semen & 46 & Industri semen \\
\hline 45 & Industri dasar besi dan baja & 47 & Industri dasar besi dan baja \\
\hline 46 & Industri logam dasar bukan besi & 48 & Industri logam dasar bukan besi \\
\hline 47 & Industri barang dari logam & 49 & Industri barang dari logam \\
\hline 48 & $\begin{array}{l}\text { Industri mesin, alat-alat dan } \\
\text { perlengkapan listrik }\end{array}$ & 50 & $\begin{array}{l}\text { Industri mesin, alat-alat dan } \\
\text { perlengkapan listrik }\end{array}$ \\
\hline 49 & $\begin{array}{l}\text { Industri alat pengangkutan dan } \\
\text { perbaikannya }\end{array}$ & 51 & $\begin{array}{l}\text { Industri alat pengangkutan dan } \\
\text { perbaikannya }\end{array}$ \\
\hline 50 & $\begin{array}{l}\text { Industri barang lain yang belum } \\
\text { digolongkan dimanapun }\end{array}$ & 52 & $\begin{array}{l}\text { Industri barang lain yang belum } \\
\text { digolongkan dimanapun }\end{array}$ \\
\hline 51 & Listrik, gas dan air bersih & 53 & Listrik, gas dan air bersih \\
\hline 52 & Bangunan & 54 & Bangunan \\
\hline 53 & Perdagangan & 55 & Perdagangan \\
\hline 54 & Restoran dan hotel & 56 & Restoran dan hotel \\
\hline 55 & Angkutan kereta api & 57 & Angkutan kereta api \\
\hline 56 & Angkutan darat & 58 & Angkutan darat \\
\hline 57 & Angkutan air & 59 & Angkutan air \\
\hline 58 & Angkutan udara & 60 & Angkutan udara \\
\hline 59 & Jasa penunjang angkutan & 61 & Jasa penunjang angkutan \\
\hline 60 & Komunikasi & 62 & Komunikasi \\
\hline 61 & Lembaga keuangan & 63 & Lembaga keuangan \\
\hline 62 & Real estat dan jasa perusahaan & 64 & Real estat dan jasa perusahaan \\
\hline 63 & $\begin{array}{l}\text { Pemerintahan umum dan } \\
\text { pertahanan }\end{array}$ & 65 & Pemerintahan umum dan pertahanan \\
\hline 64 & Jasa sosial kemasyarakatan & 66 & Jasa sosial kemasyarakatan \\
\hline 65 & Jasa lainnya & 67 & Jasa lainnya \\
\hline 66 & $\begin{array}{l}\text { Kegiatan yang tidak jelas } \\
\text { batasannya }\end{array}$ & 68 & Kegiatan yang tidak jelas batasannya \\
\hline
\end{tabular}

